Perinatology pISSN 2508-4887 • elSSN 2508-4895
Case report

Perinatology Vol. 31, No. 4, December, 2020 https://doi.org/10.14734/PN.2020.31.4.220

\section{Necrotizing Enterocolitis Associated with Norovirus Infection in a Preterm Infant}

In general, norovirus infection may cause epidemic acute gastroenteritis over all ages and may lead to self-limiting progression with typical clinical symptoms such as non-bloody diarrhea and vomiting. Premature infants diagnosed with norovirus infection have moderate to severe symptoms including a distended abdomen, apnea, hematochezia, and a rare radiologic finding called pneumatosis intestinalis. This infection is occasionally fatal in preterm infants because of their immature immune system and increased intestinal permeability to pathogens. Norovirus may cause severe illness such as hemorrhagic colitis, necrotizing enterocolitis, and colon ischemia. Outbreaks of necrotizing enterocolitis associated with norovirus infection have been reported in neonatal intensive care units. We report a case of a preterm infant diagnosed with necrotizing enterocolitis associated with norovirus.

Key Words: Caliciviridae infections, Necrotizing enterocolitis, Premature infant

\section{서론}

괴사성 장염(necrotizing enterocolitis)은 신생아에서 생명을 위협하는 소화기계 중증 질 환으로 저체중 출생아나 미숙아에서 호발한다. ${ }^{1}$ 괴사성 장염의 병태 생리는 명확하게 밝 혀지지 않았으나, 저산소증 및 허혈, 고삼투압 식이, 감염 등을 포함한 다양한 인자들에 의 해 손상 받은 미숙한 장관에 발생하는 공통점이 있으며 장의 괴사, 장천공, 복막염, 패혈증 및 사망으로 진행되기도 한다. ${ }^{2}$ 괴사성 장염의 감염원으로는 Escherichia coli, Klebsiella species, Clostridium perfringens, Staphylococcus epidermidis와 같은 세균과 로타바이러 스, 아스트로바이러스, 노로바이러스 등이 알려져 있다. 감염원 중 Clostridium perfringens, Clostridium difficile, 로타바이러스, 아스트로바이러스 등은 신생아 중환자실에서 집단감염 이 보고되었고, ${ }^{3}$ 최근 해외 사례로 노로바이러스의 집단 감염과 병발한 괴사성 장염이 보고 되었다. ${ }^{4-6}$ 국내에서도 집단감염은 아니지만 산발적으로 발생한 노로바이러스와 연관된 괴 사성 장염에 대한 보고가 있으나, ${ }^{7}$ 노로바이러스를 중점적으로 다루지 않아 논의가 필요할 것으로 사료된다. 노로바이러스는 미숙아에게 감염되었을 경우에는 복부팽만, 무호흡, 혈 변, 복강내 공기증 등의 다양한 임상 양상을 보이며 ${ }^{6}$ 괴사성 장염으로 이행되기도 한다. 로타 바이러스 백신의 도입으로 노로바이러스 감염은 상대적으로 높은 유병률을 차지하고, ${ }^{8}$ 미숙 아에서 집단감염으로 전파되거나 중증 질환으로 이행될 가능성이 있으므로 신생아 중환자 실에서는 노로바이러스 감염에 대한 대비가 필요하다. 저자는 미숙아에서 노로바이러스 감 염과 연관된 괴사성 장염 1 례를 경험하였기에 보고하는 바이다.

\section{증례}

환아는 갑작스러운 진통과 태아 둔위 위치로 재태 주수 35 주 1 일에 응급 제왕절개로 개인 산부인과에서 출생하였다. 분만 당시 1 분 및 5 분 아프가 점수는 각각 9 점, 10 점이었으며, 신 체 계측상 체중 $2.54 \mathrm{~kg}$ (50-75 백분위수), 신장 $45 \mathrm{~cm}$ (25-50 백분위수), 두위 $31 \mathrm{~cm}$ (1025 백분위수) 남아였다. 산모는 37세 초산모로 과거력상 특이 병력 및 가족력은 없었으나, 
산전검사에서 태아의 마제상 신장(horseshoe kidney) 소견이 관찰되었다. 환아는 출생 후 6시간째부터 분유수유를 시작하여 점진적 증량으로 생후 2일에는 $50 \mathrm{~mL}$ 까지 수유가 순조롭게 진 행되었다. 출생 당일에 첫 태변을 배설하였다. 생후 3 일째 환아 는 갑자기 시작된 4회의 담즙성 구토와 8회의 묽은 변을 주소로 본원 신생아 중환자실로 전원되었다.

신생아 중환자실 입원 시 활력 징후는 혈압 $66 / 44 \mathrm{mmHg}$, 맥 박수 148 회/분, 호흡 44 회/분, 체온 $36.7^{\circ} \mathrm{C}$, 대기 중 산소포화도 $100 \%$, 체중 $2.09 \mathrm{~kg}$ 으로 출생 시에 비해서 $18 \%$ 감소된 상태였 다. 신체 진찰상 창백한 전신 피부색을 보이며, 자발적 움직임
이 감소되고 처진 모습이었고, 촉진 시 숫구멍 함몰과 피부긴장 도가 저하된 상태로 탈수 소견을 보였다. 청진 시 호흡음은 정상 이었고 호흡곤란 소견은 관찰되지 않았다. 복부는 경도의 팽만 과 장음이 감소된 소견을 보였으나 촉진 시 부드러웠고 복부 내 촉지되는 종괴는 없었다. 입원 당일(제1병일)에 시행한 말초혈 액검사에서 백혈구 수 $22,460 / \mathrm{mm}^{3}$ (중성구 $25 \%$, 림프구 $20 \%$, 단핵구 $20 \%$, 호산구 $12 \%$ ), 혈색소 $16.6 \mathrm{~g} / \mathrm{dL}$, 혈소판 277,000/ $\mathrm{mm}^{3}, \mathrm{C}$-반응 단백 $8.78 \mathrm{mg} / \mathrm{dL}$ (정상 0.3 미만)로 C-반응 단백 이 상승된 소견을 보였다(Fig. 1). 혈청 나트륨 $154 \mathrm{mmol} / \mathrm{L}$, 혈 청 칼륨 $4.4 \mathrm{mmol} / \mathrm{L}$, 혈액요소질소 $16.2 \mathrm{mg} / \mathrm{dL}$, 혈청 크레아티

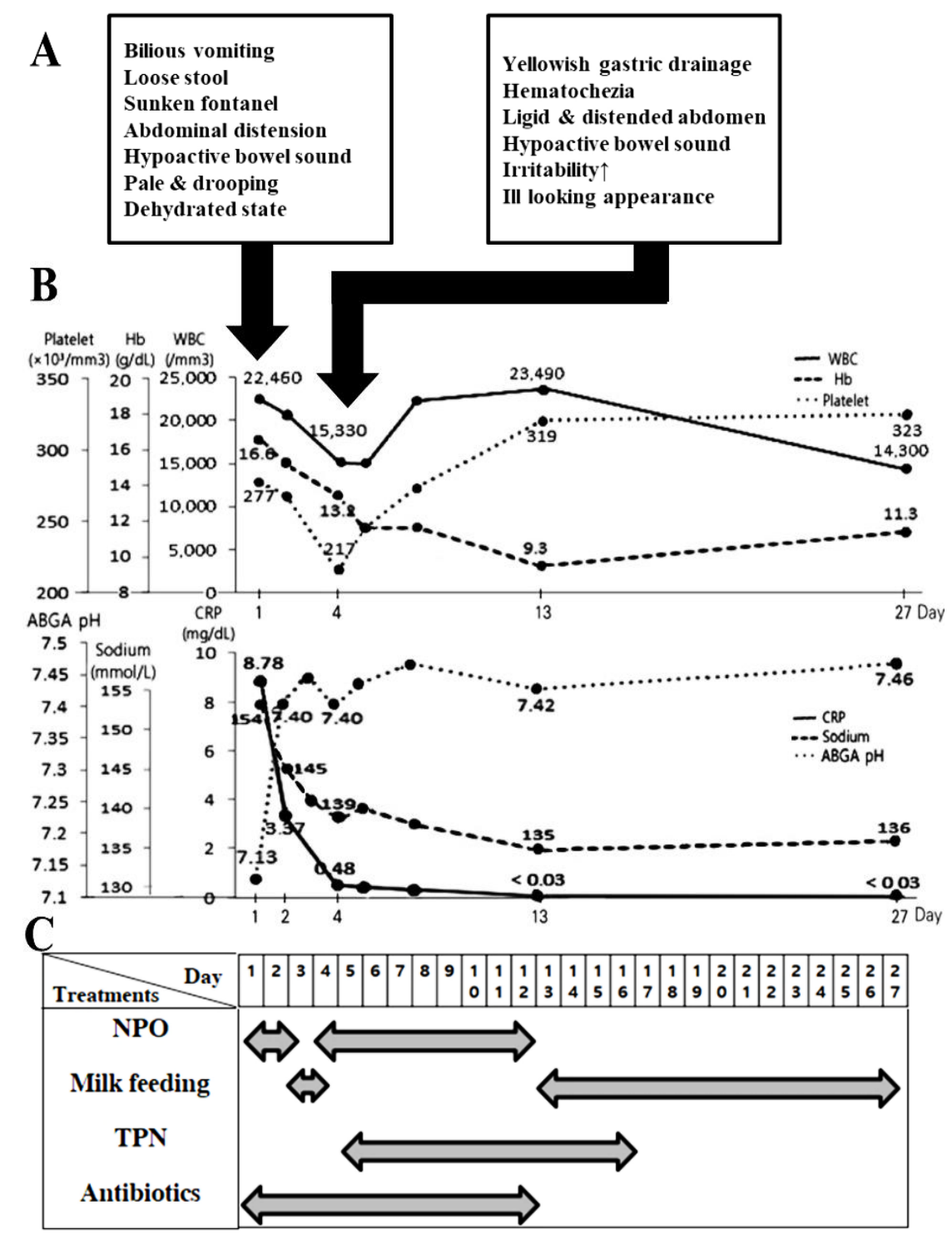

Fig. 1. The course of $(A)$ clinical features, $(B)$ laboratory findings and $(C)$ treatments. WBC, white blood cell; $\mathrm{Hb}$, hemoglobin; $\mathrm{CRP}, \mathrm{C}$-reactive protein; $\mathrm{ABGA}$, arterial blood gas analysis; NPO, nil per os; TPN, total parenteral nutrition. 
닌 $1.26 \mathrm{mg} / \mathrm{dL}$, 혈청 칼슘 $7.6 \mathrm{mg} / \mathrm{dL}$, 혈청 aspartate transaminase $35 \mathrm{IU} / \mathrm{L}$, 혈청 alanine transaminase $8 \mathrm{IU} / \mathrm{L}$, 혈청 총 빌리 루빈 $1.6 \mathrm{mg} / \mathrm{dL}$, 혈청 암모니아 $103 \mu \mathrm{g} / \mathrm{dL}$, 혈당 $85 \mathrm{mg} / \mathrm{dL}$, 동 맥혈 가스분석검사상 $\mathrm{pH} 7.13, \mathrm{pCO}_{2} 24 \mathrm{mmHg}, \mathrm{pO}_{2} 73 \mathrm{mmHg}$, $\mathrm{HCO}_{3}{ }^{-} 8.0 \mathrm{mEq} / \mathrm{L}$, base excess $-19.3 \mathrm{mEq} / \mathrm{L}$ 로 고나트륨혈 증을 동반한 대사성 산증 소견을 보였다(Fig. 1). 백혈구 수와

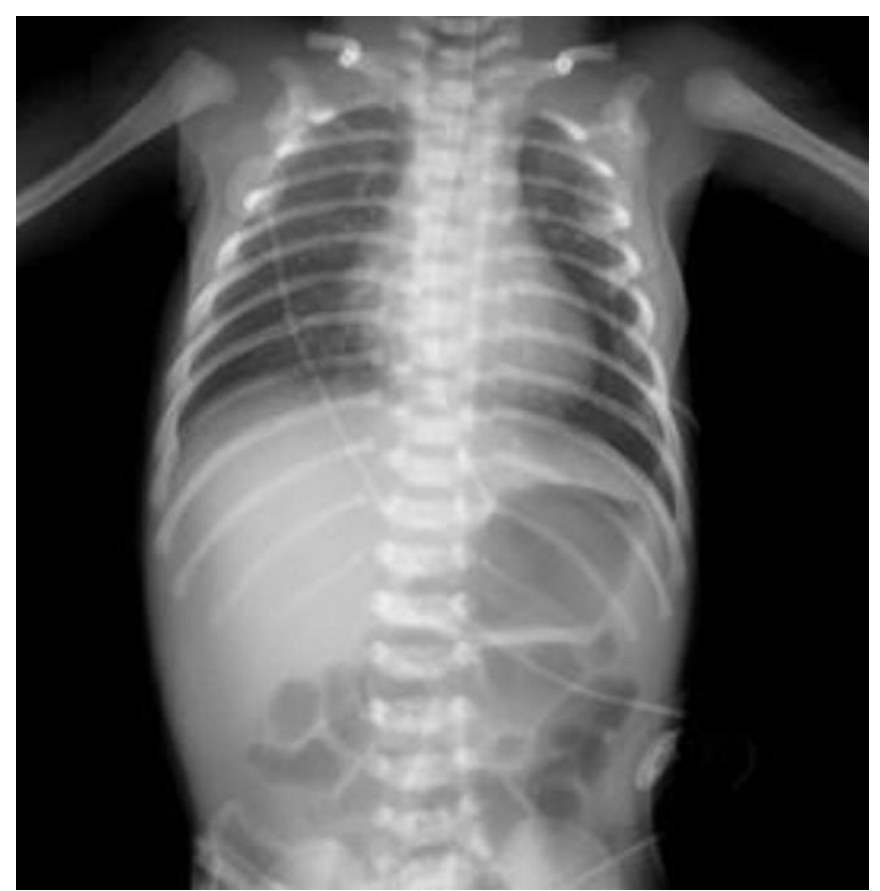

Fig. 2. Plain abdominal X-ray shows non-specific stomach and bowel pattern at first day of hospitalization.
$\mathrm{C}$-반응 단백 상승으로 위장관 감염 외에 뇌수막염과 패혈증 을 의심하여 각종 배양검사와 뇌척수액검사를 실시하였다. 제 1 병일에 실시한 혈액 세균배양검사, 대변 로타바이러스항원검 사, 대변 세균(Vibrio species, Campylobacter species, Shigella species, Salmonella species, Clostridium difficile toxin B, Yersinia enterocolitica, Aeromonas species, Escherichia coli O157:H7, Verotoxin-producing Escherichia coli, Clostridium perfringens)과 바이러스(아스트로바이러스, 로타바이러스, 아 데노바이러스, 노로바이러스 GI, GII) multiplex real-time reverse transcription polymerase chain reaction (RT-PCR), 대 변잠혈검사 모두에서 음성이었고, 뇌척수액검사에서도 특이 소 견은 보이지 않았다. 제 1 병일에 촬영한 흉부 복부 방사선 사진상 특이 소견이 없었고(Fig. 2), 복부 초음파검사상에서도 마제상 신장 소견 외에 특이 소견은 없었다. 제 1 병일부터 광범위 항생 제(ampicillin, gentamycin)를 투여하였고, 대사성 산증과 고장 성 탈수 치료를 위해서 금식, 중탄산나트륨 투여, 수액 요법을 실 시하였다. 제 2 병일에 시행한 혈청 나트륨은 $145 \mathrm{mmol} / \mathrm{L}$, 동맥 혈 가스분석검사상 $\mathrm{pH} 7.40, \mathrm{pCO}_{2} 29 \mathrm{mmHg}, \mathrm{pO}_{2} 156 \mathrm{mmHg}$, $\mathrm{HCO}_{3}{ }^{-} 18.0 \mathrm{mEq} / \mathrm{L}$, base excess $-5.5 \mathrm{mEq} / \mathrm{L}$ 로 호전되었다 (Fig. 1), 환아는 금식 이후로 소량의 담즙색 위관배액과 1회의 묽은 변 배출 소견을 보였으나, 이후로 담즙색 위관배액, 구토, 설사 증상 없이 양호하였다. 제 3 병일에는 체중 $2.41 \mathrm{~kg}$ 으로 증 가하였고, 탈수 상태가 교정되고, 전신 상태가 호전되었으며, 복 부 방사선 사진과 신체 진찰상 특이 소견이 보이지 않아서 분유 수유를 개시하였다. 환아는 24 시간 동안 잔류량 없이 수유 받았 고, 정상 변이 1 회 배출되었으나, 제 4 병일에 짜증스러운 울음 소

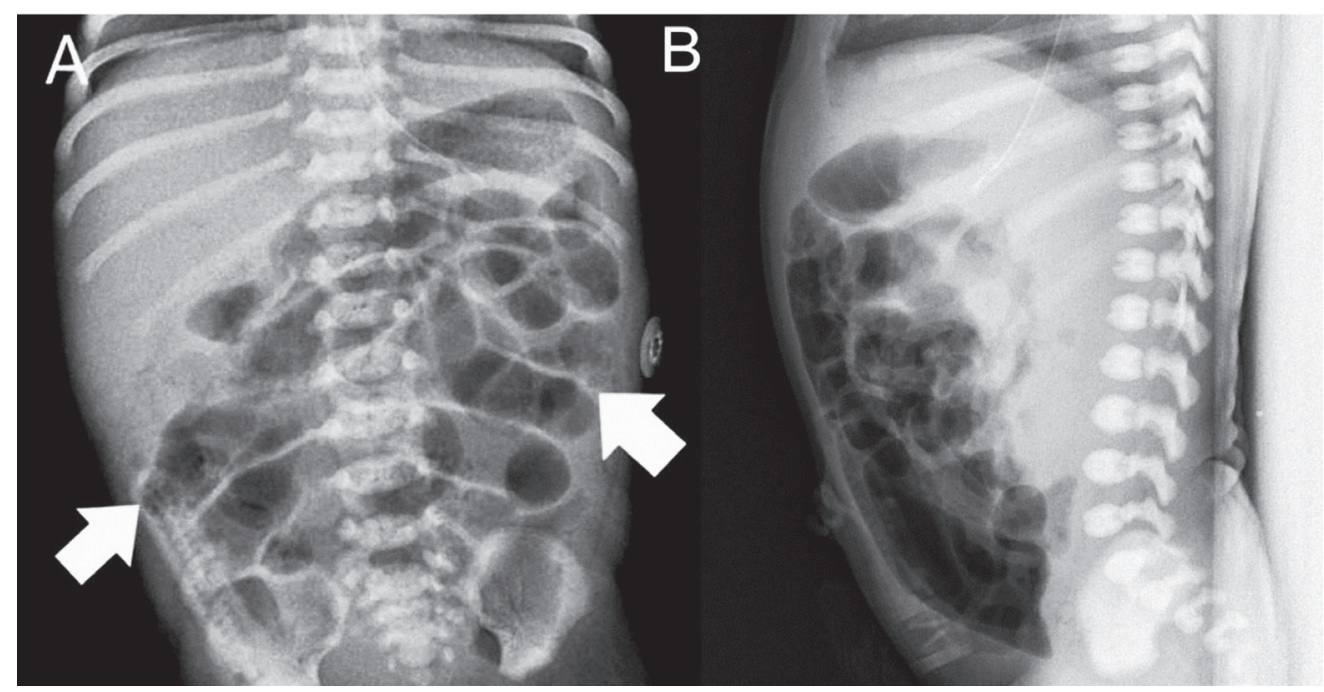

Fig. 3. (A) Anterior-posterior abdominal X-ray shows dilatation of bowels and soap bubble appearance of pneumatosis intestinalis (arrows), which means necrotizing enterocolitis, at fourth day of hospitalization. (B) Cross-table lateral abdominal X-ray shows dilatation of bowels. 
리와 아픈 모습과 복부팽만이 관찰되었으며, 복부 촉진 시 단단 한 느낌과 청진 시 장음이 감소된 소견, 5 회의 혈변, 노란색의 위 관 배액량이 관찰되었다. 복부 방사선 사진상 장이 늘어나 있고 (dilatation of bowel), 장벽내 공기(pneumatosis intestinalis)가 보였으며(Fig. 3), 복부 초음파검사에서는 창자 벽은 두꺼워져 있으나, 장벽내 공기와 문맥정맥내 공기(portal venous gas)의

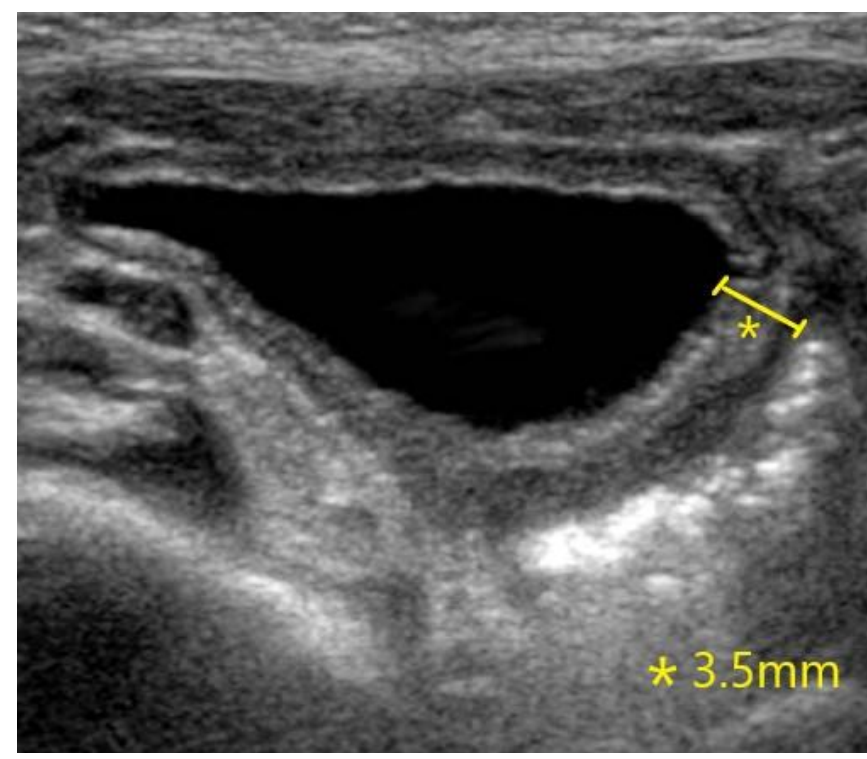

Fig. 4. Abdominal ultrasonography of sigmoid colon reveals bowel wall thickening without significant intra-luminal air at fifth day of hospitalization. The thickness of sigmoid colon is $3.5 \mathrm{~mm}$ (asterisk).

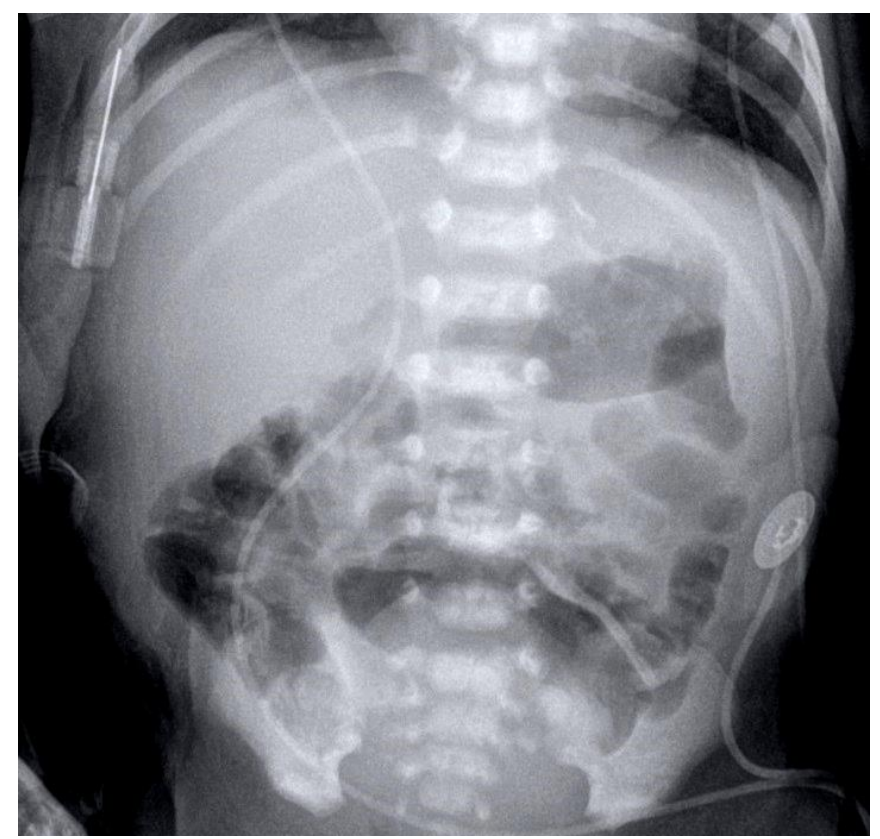

Fig. 5. Plain abdominal X-ray shows non-specific stomach and bowel pattern at thirteenth day of hospitalization.
증거는 보이지 않았다(Fig. 4). 이때 시행한 혈액검사에서는 특 이 소견은 없었다(Fig. 1). 대변의 바이러스 RT-PCR 검사를 재 시행하였고, 노로바이러스 GII 양성, 대변잠혈검사 양성 소견을 보였다. 환아는 modified Bell's staging criteria ${ }^{9}$ 기준으로 병기 $\mathrm{IIA}$ 의 괴사성 장염으로 진단되었고 총 12 일간 금식, 위관을 통 한 복부 감압 처치, 중심정맥관을 이용한 총 정맥영양과 항생제 (amikacin, vancomycin, metronidazole) 투여 치료를 실시하였 다. 환아는 제 13 병일에 무증상으로 신체검진상 특이 소견을 보 이지 않고, 혈액검사, 복부 방사선검사(Fig. 5), 대변잠혈검사상 정상 소견으로 소량의 희석된 가수분해분유 수유를 시작하였 다. 이후 매일 복부 상태, 위 잔류량 확인을 실시하면서 점진적 으로 수유량이 증량되어 제 24 병일에 $50 \mathrm{~mL}$ 까지 경구 수유가 완성되었고, 제 27 병일에 체중 $2.92 \mathrm{~kg}$ 으로 건강한 상태로 퇴원 하였다. 이후 환아는 4 달째 외래 추적 관찰 중으로 위장관 증상 없이 건강하게 성장 발달 중에 있다.

\section{고찰}

괴사성 장염은 미숙아에서 가장 흔한 응급 위장관 질환으로, 발생 빈도는 1,000 명의 신생아에서 1-3명이지만 저출생 체중 아는 2-5\%에서 신생아 중환자실 입원환자의 경우에는 1-8\% 가 괴사성 장염으로 진단된다. ${ }^{1}$ 미숙아, 비정상적 미생물 구성 (microbial colonization), 모유수유 부족 등이 잘 알려진 괴사성 장염 발생의 위험 요소이며, ${ }^{3}$ 그외 세균의 내독소, 미숙한 면역 체계에 기인한 과도한 염증 유발 반응, Toll-like receptor 증가, 저산소증, 허혈, 재관류, 저체온증 등의 다양한 인자들이 미숙한 장관에 영향을 미쳐 괴사성 장염이 발생되는 것으로 추정된다. ${ }^{10}$

괴사성 장염을 일으키는 세균은 주로 그람음성균이며, Enterobacteriaceae, Klebsiella species, Pseudomonas species, Clostridium species, Staphylococcus species 등이 있다. ${ }^{3}$ 미 숙아의 장내 세균 분포는 구성면에서 만삭아에 비해 장내 세균 종류의 다양성이 미흡하다고 알려져 있다. ${ }^{11}$ Penders 등 ${ }^{12}$ 이 재 태 주수 37 주 미만으로 출생한 미숙아에서 생후 1 개월에 대변 내 세균 분석 결과, 미숙아는 만삭아에 비해 Bifidobacterium species 집락수가 적었고, Clostridium difficile 집락수가 많았 다. Pammi 등 ${ }^{13}$ 은 괴사성 장염이 발병했던 미숙아들의 장내 세 균 특성에 대한 메타 분석 연구를 실시하였고, 괴사성 장염을 않은 미숙아는 괴사성 장염을 않지 않은 미숙아에 비해서 장내 에 Proteobacteria가 많고 Firmicutes와 Bacteroidetes는 적다 는 특징을 보고하였다. 이렇게 만삭아와 다른 미숙아의 장내 세 균 불균형(dysbiosis)은 괴사성 장염이 호발하는 환경으로 작용 
할 수 있다.

미숙아는 만삭아에 비해 면역체계가 미성숙하고, 미생물의 점액막 투과도가 높으며, 혈액내 immunoglobulin G 항체의 양 이 적고, 식세포 작용, 면역글로불린 생성, T림프구의 기능 등의 방어체계가 미약하여, 병원체 접촉으로 인한 감염에 취약한 특 징이 있다. ${ }^{14}$ 본 증례와 같은 후기 미숙아(재태 주수 34주 0일-36 주 6일)는 초극소 미숙아에 비해 만삭아에 가까운 재태 주수와 생 김새를 보여, 출생 이후에는 정상 신생아실에서 만삭아와 유사 하게 처치되는 등 만삭아와 같은 신체 성숙 상태로 오인되는 경 향이 있다. ${ }^{15}$ 그러나, 후기 미숙아는 뇌와 폐 등의 기관 발달에 중요한 마지막 6 주의 재태 기간을 모체 내에서 정상적으로 보내 지 못해서 만삭아와 비교할 때 호흡기 질환, 수유 곤란, 저체온, 저혈당, 황달 등 각 종 질환의 고위험군으로 알려져 있으며, ${ }^{16}$ 면 역 체계 미숙으로 감염병의 유병률도 높다. ${ }^{15}$ 건강한 만삭아와 소아에서는 단순 위장관염을 일으키는 바이러스가 감염에 취약 한 미숙아에서는 괴사성 장염의 원인이 되기도 한다. ${ }^{17}$ 실제로 로타바이러스, 노로바이러스, 코로나바이러스, 아스트로바이러 스, 엔테로바이러스에 의한 신생아 중환자실 집단 감염으로 인 한 괴사성 장염의 사례들이 보고되어 있다. ${ }^{3}$ 그외 집단 감염 사 례는 아니지만 거대세포바이러스, 에코바이러스, 인간면역결핍 바이러스 등이 괴사성 장염의 원인으로 보고되고 있다. ${ }^{3}$

이 중 노로바이러스는 전 세계적으로 전 연령층에 걸쳐서 위 장관염의 가장 흔한 원인으로 ${ }^{8} 18 \%$ 를 차지하고 있다. ${ }^{18}$ 과거에 는 로타바이러스가 위장관염의 가장 흔한 원인이었으나 예방접 종이 실시되면서 유병률이 감소하였고, 상대적으로 노로바이러 스 유병률은 높게 유지되고 있다. ${ }^{8}$ 노로바이러스는 겨울철에 주 로 유행하며, ${ }^{3}$ 오심, 구토, 설사, 복통, 발열 등의 증상을 보이는 전형적인 급성 위장관염의 형태로 병발하는데, 대부분 임상 경 과가 양호하다. ${ }^{6}$ 분변경구 감염 경로를 통해 전파되고, 바이러 스 개체수 10 개 미만의 적은 수의 바이러스에 의해서도 전염이 될 수 있다. ${ }^{6}$

미숙아에서 노로바이러스 감염의 증상은 다양하게 나타날 수 있다. Naing 등 ${ }^{14}$ 은 재태 주수 32 주 미만의 미숙아를 대상으로 대변에서 노로바이러스 GII 외에 8종의 바이러스 RT-PCR 검 사를 시행하여 미숙아의 대변에서 자주 검출되는 바이러스의 현황에 대해 보고하였는데, 미숙아 75 명 중 $17 \%$ (13례)에서 특 정 바이러스가 진단되었고, 이 중에서 노로바이러스 GII는 $54 \%$ (7례/13례)로 가장 많이 진단되었다. 노로바이러스 GII가 진단 된 미숙아 중 5 명은 무증상, 2 명은 유증상 감염이었고, 증상으 로는 설사, 무호흡, 혈소판 감소증, 패혈증과 같은 임상 양상을 보였다. Tzialla 등 ${ }^{6}$ 은 신생아 중환자실에서 노로바이러스에 집 단 감염된 27례를 보고하였는데, 이들은 재태 주수 25-40주(중
간값 33.7주), 체중 606-3,900 g의 신생아로 27례 중 5례는 무 증상 감염이었고, 유증상 감염은 22 례였다. 증상으로는 복부 팽 만이 18례(81.8\%)로 가장 많았고, 혈변이 15례(68.2\%)에서 나 타났으며, 그 밖에 설사, 패혈증과 같은 양상, 구토, 위저류의 기 타 증상이 있었고, 유증상 감염 22 례 중 16례(72.7\%)에서 복벽 내 공기증, 장천공이 나타나 Bell stage 2-3의 괴사성 장염으로 진단되었다. 과거에는 주로 세균 감염이 괴사성 장염을 일으키 는 병인으로 생각되었지만, 신생아 중환자실 내에서 노로바이 러스 집단 감염이 발생하였을 때, 임상 양상이 괴사성 장염으로 진행될 수 있음을 보여주는 사례이다. Turcios-Ruiz 등 ${ }^{5}$ 은 재 태 주수 34 주 미만으로 출생한 미숙아에서 노로바이러스 감염 과 연관된 괴사성 장염 8례를 보고하였다. 발병 시기는 겨울이 었고, 괴사성 장염을 않은 미숙아는 복부 팽만, 무호흡, 위저류 의 증상을 보였고, 혈액검사에서 띠중성구(band neutrophil)가 감소되어 있었다. 괴사성 장염을 않지 않았던 미숙아에 비하여 상대적으로 나이가 어리고, 아프가 점수가 낮고, 항생제 투약 일 수가 길었던 특징이 있었다. 이와 같이 미숙아에서 노로바이러 스 감염은 무증상을 비롯하여 다양한 임상 양상을 보이며, 드물 게는 출혈성 위장염, 괴사성 장염과 같은 중증 질환으로 이환되 기도 하므로, ${ }^{17}$ 노로바이러스 유행시기에는 신생아 중환자실내 바이러스 유입을 차단하려는 노력과 발생시에는 집단 감염으로 확대될 수 있는 가능성을 염두에 두고 대비하는 것이 필요할 것 으로 사료된다.

노로바이러스에 의한 괴사성 장염을 임상적으로 구별하기는 어렵지만, 바이러스가 검출된 경우에는 노로바이러스를 괴사성 장염을 일으킨 병인으로 추정해 볼 수 있다. ${ }^{5}$ 노로바이러스의 진단은 enzyme-linked immunosorbent assay (ELISA), RT$\mathrm{PCR}$, 전자현미경검사를 이용할 수 있으며, 각 검사법들의 특이 도는 $90 \%$ 이상이다. ${ }^{3}$ 그러나 개별 검사 간의 결과값은 불일치를 보이는 경우가 있으므로, 3 가지 검사 중 2 가지 검사 이상에서 양 성인 경우에 노로바이러스 감염으로 확진할 수 있다. ${ }^{3}$ 본 증례는 제 1 병일에 시행하였던 분변의 RT-PCR 검사는 음성이었고, 제 4 병일에 재차 시행한 검사에서는 양성으로 확인되었다. 이 경우 에 병의 초기 단계에는 바이러스 양이 적어서 위음성의 결과가 나오고 수일 뒤 바이러스가 증폭되면서 양성의 결과가 나올 수 있지 않았나 추정해 볼 수 있다. 또한 처음부터 동일 검체로 2 가 지 이상의 검사 방법을 동시에 시행하여 비교하였다면 신속하 고 정확하게 진단이 가능했을 것으로 생각된다.

최근 들어 미숙아에서 중증의 괴사성 장염은 모유수유, 항생 제 및 $\mathrm{H}_{2}$ antagonist 투약 감소로 그 예방 효과가 알려지면서, 전 세계적으로 발병률이 감소하고 있다. ${ }^{19}$ 과거 괴사성 장염의 병인은 주로 세균으로 알려져 왔지만, 최근에는 바이러스의 진 
단 기술이 발전하면서, 바이러스가 괴사성 장염의 병인으로 대 두되고 있다. ${ }^{3}$ 우리나라의 경우에는 최근 산모의 산후조리원 이 용이 증가하고, 신생아가 산후조리원에 입소하여 집단 생활하 는 사례가 늘어나면서, 신생아 바이러스 위장관염의 발생 빈도 가 증가하고 있다. 산후조리원의 신생아 로타바이러스 집단 감 염 등의 사례가 알려지기도 하였다. ${ }^{20}$ Moon 등 20 은 급성 바이 러스성 장염이 의심되는 만삭아 112 명을 대상으로 4 종 바이러 스의 양성률을 연구하였다. 대변바이러스검사 양성률은 $33 \%$ 였 고, 이 중에서 로타바이러스가 $59.5 \%$ 로 가장 많았고, 아스트로 바이러스가 $29.7 \%$, 노로바이러스가 $10.8 \%$ 에서 검출되었으며, 아데노바이러스는 검출되지 않았다. 입원 전까지 생활했던 장 소는 조리원이 $74.1 \%$ 였던 것으로 보아, 집단 생활 환경이 급성 바이러스성 장염 발병에 영향을 끼쳤을 것으로 추정해 볼 수 있 다. ${ }^{20}$ 급성 위장관염의 증상을 호소하는 외부 신생아가 신생아 중환자실에 입원하게 되면, 신생아 중환자실 원내 감염의 전파 원인으로 작용할 수 있다. 특히, 감염에 취약한 미숙아에서는 특 정 바이러스에 의한 집단 감염으로 발생할 수 있고, 이 중 미숙 아의 노로바이러스 감염은 본 증례에서와 같이 괴사성 장염으 로 진행될 수 있다. ${ }^{17}$ 따라서, 입원 초기에 병인이 되는 바이러스 를 정확하게 감별하는 것이 중요하다. 로타바이러스 백신의 도 입으로 노로바이러스 감염은 상대적으로 높은 유병률을 차지하 고 있으므로, 위장관염이나 괴사성 장염이 의심되는 미숙아에 서 로타바이러스 외에도 노로바이러스의 대변 RT-PCR 검사와 ELISA 혹은 신속항원법 등의 2가지 검사를 함께 시행하여 진단 율을 높이는 것이 괴사성 장염의 병인을 밝히는 데에 유용할 것 으로 사료된다.

\section{Conflict of interest}

No potential conflict of interest relevant to this article was reported.

\section{References}

1) Tudehope DI. The epidemiology and pathogenesis of neonatal necrotizing enterocolitis. J Paediatr Child Health 2005;41:167-8.

2) Srinivasan PS, Brandler MD, D'Souza A. Necrotizing enterocolitis. Clin Perinatol 2008;35:251-72, x.

3) Coggins SA, Wynn JL, Weitkamp JH. Infectious causes of necrotizing enterocolitis. Clin Perinatol 2015;42:133-54, ix.

4) Stuart RL, Tan K, Mahar JE, Kirkwood CD, Andrew Ramsden C, Andrianopoulos N, et al. An outbreak of necrotizing enterocolitis associated with norovirus genotype GIl.3. Pediatr Infect Dis J 2010;29:644-7.

5) Turcios-Ruiz RM, Axelrod P, St John K, Bullitt E, Donahue J, Robinson N et al. Outbreak of necrotizing enterocolitis caused by norovirus in a neonatal intensive care unit. J Pediatr 2008;153:339-44

6) Tzialla C, Civardi E, Borghesi A, Sarasini A, Baldanti F, Stronati M. Emerging viral infections in neonatal intensive care unit. J Matern Fetal Neonata Med 2011;24 Suppl 1:156-8.

7) Kim YH, Seo EJ, Shim GH, Chey MJ. Comparison of virus-associated necrotizing enterocolitis and non-virus necrotizing enterocolitis in neonatal intensive care unit. Korean J Perinatol 2011;22:295-302.

8) Lopman BA, Steele D, Kirkwood CD, Parashar UD. The vast and varied global burden of norovirus: prospects for prevention and control. PLoS Med 2016;13:e1001999

9) Bell MJ, Ternberg JL, Feigin RD, Keating JP, Marshall R, Barton L, et al. Neonatal necrotizing enterocolitis. Therapeutic decisions based upon clinical staging. Ann Surg 1978;187:1-7.

10) Prado C, Michels M, Ávila P, Burger H, Milioli MVM, Dal-Pizzol F. The protective effects of fecal microbiota transplantation in an experimenta model of necrotizing enterocolitis. J Pediatr Surg 2019;54:1578-83.

11) Torrazza RM, Neu J. The altered gut microbiome and necrotizing en terocolitis. Clin Perinatol 2013:40:93-108.

12) Penders J, Thijs C, Vink C, Stelma FF, Snijders B, Kummeling I, et al. Factors influencing the composition of the intestinal microbiota in early infancy. Pediatrics 2006;118:511-21.

13) Pammi M, Cope J, Tarr PI, Warner BB, Morrow AL, Mai V, et al. Intestina dysbiosis in preterm infants preceding necrotizing enterocolitis: a sys tematic review and meta-analysis. Microbiome 2017;5:31.

14) Naing Z, Rayner B, Killikulangara A, Vunnam K, Leach S, Mclver CJ, et al. Prevalence of viruses in stool of premature neonates at a neonatal intensive care unit. J Paediatr Child Health 2013;49:E221-6.

15) Isayama T, Lewis-Mikhael AM, O'Reilly D, Beyene J, McDonald SD. Health services use by late preterm and term infants from infancy to adulthood: a meta-analysis. Pediatrics 2017;140:e20170266.

16) Snyers $D$, Lefebvre $C$, Viellevoye $R$, Rigo V. Late preterm: high risk new borns despite appearances. Rev Med Liege 2020;75:105-10.

17) Bagci $S$, Eis-Hübinger $A M$, Yassin $A F$, Simon $A$, Bartmann $P$, Franz $A R$, et al. Clinical characteristics of viral intestinal infection in preterm and term neonates. Eur J Clin Microbiol Infect Dis 2010;29:1079-84.

18) Ahmed $S M$, Hall AJ, Robinson $A E$, Verhoef $L$, Premkumar $P$, Parashar UD, et al. Global prevalence of norovirus in cases of gastroenteritis: a systematic review and meta-analysis. Lancet Infect Dis 2014;14:725-30.

19) Patel AL, Panagos PG, Silvestri JM. Reducing incidence of necrotizing enterocolitis. Clin Perinatol 2017:44:683-700.

20) Moon SK, Lee JI, Yoon HS, Ahn YM. Isolation rate of 4 type virus of acute gastroenteritis in full-term neonates during neonatal period. Clin Exp Pediatr 2007;50:855-61 